\title{
Př́padová studie vlivu stáří vozidel na zranění cestujících
}

\author{
Roman Mikulec ${ }^{\mathrm{a}^{*}}$, Pavlína Dvořáková ${ }^{\mathrm{b}}$ \\ ${ }^{a}$ Centrum dopravního výzkumu, Brno \\ bVysoké učení technické v Brně, Ústav soudního inženýrství
}

Case Study of Vehicle Age Influence on Passenger Injury

\begin{abstract}
Abstrakt
Článek poukazuje na pokroky $\mathrm{v}$ automobilovém průmyslu a rozdíly v konstrukci a vybavenosti starých a nových vozidel. Při dopravní nehodě představuje struktura karoserie vozidla důležitou součást pasivní bezpečnosti, která má zásadní vliv na bezpečnost posádky ve vozidle. K porovnání tuhostí karoserie a vybavení zádržnými systémy starých a nových vozidel jsou využity př́ípadové studie $\mathrm{z}$ reálných dopravních nehod. Studie rovněž porovnává závažnost zranění posádky v souvislosti se stárím vozidel.
\end{abstract}

Klíčová slova: vozidlo, stáří vozidel, boční nárazy, zranění cestujících.

\section{1. ÚVOD}

Vývoj v oblasti automobilového průmyslu směřuje $\mathrm{k}$ zajištění vyšší bezpečnosti provozu vozidel na pozemních komunikacích. Milníkem v této oblasti v Evropě bylo zavedení homologačních nárazových testů nových vozidel Euro NCAP v roce 1997 a jejich hodnocení pomocí počtu hvězdiček. V důsledku těchto testů začali jednotliví automobiloví výrobci výrazně zlepšovat prvky pasivní a následně i aktivní bezpečnosti vozidel. Inovace těchto prvků (využívání vysokopevnostních materiálů, rozšíření airbagů, povinná výbava vozidel systémy ABS a ESP, atd.) ve vozidlech vede ke snížení počtu závažných zranění během nehodového děje, nebo dokonce jejich eliminaci. Jedná se zejména o zamezení nadměrného pohybu cestujících ve vozidle (bezpečnostní pásy s předpínači) a omezení kontaktu cestujících s tvrdými částmi interiéru vozidla, nebo vnikání vnějších objektů do prostoru pro cestující (airbagy, struktura karoserie).

Dle statistik Svazu Dovozců Automobilů (SDA) je průměrné stáří vozidel registrovaných v České republice 14,6 roku. U vozidel staršího data výroby prritom hrozí snížení účinnosti ochrany

\begin{abstract}
This article highlights the advances in the automotive industry and the differences in design and safety features of old and new vehicles. In a traffic accident, the structure of the vehicle body is an important part of passive safety that has a major impact on the safety of the passengers in the vehicle. A case studies of real traffic accidents are used to compare the stiffness of the old and the new vehicles and their equipment by restraint systems. The study also compares passengers' injuries in relation to vehicle age.
\end{abstract}

Keywords: vehicle, vehicle age, side impact, passenger injury.

posádky, a to vlivem koroze nosných částí vozidla, či omezením funkce zádržných systémů (např. degradací pyrotechnického spouštěče airbagů). Na zvýšené riziko zranění cestujících ve starších vozidlech bylo poukázáno v [2], [8]. Viz tab.1.

Oproti starším vozidlům je u moderních vozidel pro jejich konstrukci využíváno vysokopevnostních materiálů, které pomáhají chránit posádku vozidla, a to především před deformací prostoru pro cestující. Současné technologie umožňují výrobcům nových vozidel využívat pokročilé numerické simulace k testování odolnosti využívaných a vyvíjených materiálů, které jsou použity při konstrukci vozidla. Využívání numerických simulací např. při návrhu deformačních zón, zvýšení odolnosti vozidla při nárazu apod. značně snižuje náklady na jejich testování [6]

I přes výše zmíněný vývoj v oblasti bezpečnosti vozidel však určité typy střetů zůstávají nadále problematickými bez ohledu na stáří vozidel. Jedněmi z nich jsou střety boční. Těmi se v rámci vyhodnocení bočních nárazových zkoušek zabývali např. autoři článku [10]. Cestující je ve vozidle chráněn prakticky jen dveřmi vozidla, které svou konstrukcí v mnoha případech 
Tab. 1 Nejvyšši zaznamenaná zraněni u dopravnich nehod osobních vozidel v souvislosti se stářim vozidel. Tab. 1 The highest documented injury during vehicle traffic accident in relation to vehicle age.

\begin{tabular}{lccc}
\hline Zranění & $\begin{array}{c}\text { Vozidla vyrobená } \\
\text { do roku 2000 }\end{array}$ & $\begin{array}{c}\text { Vozidla vyrobená mezi } \\
\text { lety 2001 a 2010 }\end{array}$ & $\begin{array}{c}\text { Vozidla vyrobená mezi } \\
\text { lety 2011 a 2018 }\end{array}$ \\
\hline Bez zranění & $21,3 \%$ & $32,1 \%$ & $37,4 \%$ \\
Lehké zranění & $63,0 \%$ & $58,7 \%$ & $55,0 \%$ \\
Těžké zranění & $9,2 \%$ & $7,1 \%$ & $4,5 \%$ \\
Smrtelné zranění & $6,5 \%$ & $2,1 \%$ & $3,2 \%$ \\
\hline
\end{tabular}

nejsou schopny zamezit deformaci prostoru pro cestující nebo vniknutí vnějšího objektu do vozidla a následnému kontaktu s cestujícím. Z důvodu omezeného prostoru mezi konstrukcí vozidla a cestujícím je zapotřebí ve zvýšené míře využívat moderní vysokopevnostní materiály, které i přes nedostatek deformačních zón absorbují vyšší deformační energii, čímž snižují závažnost zranění. [11]

Dalším významným faktorem, který se podílí na snížení následků kolizí vozidel, je použití vyššího počtu zádržných systémů; v př́padě bočních střetů se jedná zejména o boční airbagy. Např́iklad ve studii [7] dospěli autoři k závěru, že ve vozidlech vybavených hlavovými airbagy hrozí o $75 \%$ menší riziko poranění hlavy při střetu ze strany cestujícího. Ochrana cestujících bočními airbagy je však nižší, pokud je vozidlo vybaveno pouze torzními airbagy, jak je např́íklad uvedeno v [5] nebo [4].

Řada studií [1], [3], [9] se zabývala zraněními, která cestující utrpí při bočních nárazech. Jejich závěrem bylo, že při bočních nárazech dochází nejčastěji k poranění hlavy, hrudníku a krku. $\mathrm{K}$ těmto poraněním dochází především kvůli setrvačnému pohybu těla (zejména jeho horní poloviny), který je směřován proti boku vozidla. Při tomto pohybu těla bezpečnostní pásy do jisté míry ztrácejí svou účinnost a zádržnou schopnost. $\mathrm{V}$ těchto případech, zejména pak v kombinaci s absencí bočních airbagů (především u starších vozidel) a s rizikem deformace boční struktury vozidla (a jejím průnikem do interiéru), dochází k závažným poraněním cestujících, a to mnohdy i při relativně nízkých střetových rychlostech. Je proto nutné, aby byla karoserie vozidla v kritických místech dostatečně vyztužená, aby pohltila co nejvíce energie a došlo tak k co nejmenší deformaci a ke snížení následků na lidském životě.

Tato př́padová studie poskytuje srovnání bočních střetů a jejich následků u vozidel vyrobených do roku 2000 s vozidly moderní konstrukce nejen v př́padě střetu s jiným vozidlem, ale rovněž v případě kolize s pevnou překážkou.

\section{DATA}

\subsection{Sběr dat}

Veškeré údaje, použité $\mathrm{v}$ tomto článku, byly získány $\mathrm{v}$ rámci projektu Hloubkové analýzy dopravních nehod (HADN), na kterém se podílely Centrum dopravního výzkumu, v.v.i. a společnost IDIADA CZ a.s. Metodika sběru dat byla převzata $\mathrm{z}$ německého výzkumu dopravních nehod German In-Depth Accident Study (GIDAS). V rámci tohoto projektu je prováděna detailní dokumentace dopravních nehod, spočívající ve fotodokumentaci místa nehody a zúčastněných vozidel, geodetickém zaměření místa nehody a, pokud je to možné, provedení rozhovoru s účastníky nehody. Ze smluvních nemocničních zařízení jsou pak zpětně získávány informace o zranění účastníků šetřených nehod. Veškeré získané údaje jsou anonymizovány.

\subsection{Vyhodnocení dat}

Na základě dokumentace dopravních nehod a jejich následků $\mathrm{v}$ rámci projektu HADN jsou analyzovány veškeré faktory, které se podílely na jejich vzniku. Výstupem projektu jsou návrhy opatření, které mají za cíl zmírnění následků dopravních nehod, nebo jejich úplnou prevenci.

Informace získané na místě nehody - tedy stav dopravní infrastruktury (stav pozemní komunikace, podélné a příčné sklony, stav dopravního značení, přehlednost místa nehody, aj.), rozsah a způsob poškození zúčastněných vozidel a informace o zranění posádky vozidel slouží dále pro účely detailní analýzy a rekonstrukce předmětné dopravní nehody. Ta slouží především k určení technicky přijatelných rychlostí v okamžiku kolize, pro porovnání s informacemi od účastníků dopravní nehody a posouzení jejich technické přijatelnosti. Stanovení střetové rychlosti vozidel bylo provedeno na základě posouzení rozsahu deformací šetřených vozidel pomocí EES katalogu [12]. Takto určená rychlost byla dále ověrena $\mathrm{v}$ průběhu vlastní rekonstrukce dopravních nehod, které byly prováděny s podporou simulačního programu Virtual Crash 4.0.

\section{PŘÍPADOVÉ STUDIE}

Následujících 6 prrípadů (tři dvojice vozidel různého stáŕí, podobný způsob nárazu) byly vybrány za účelem představení rozdílu následků bočních kolizí starých a nových vozidel při obdobných střetových konfiguracích, střetových rychlostech a hmotnostech vozidel.

\subsection{Př́ípad 1}

K dopravní nehodě došlo na frekventované silnici v extravilánu, přičemž řidič vozidla Suzuki Swift z neznámých prŕčin přejel do protisměru, dostal smyk a bočně do vozidla Suzuki narazilo protijedoucí vozidlo Škoda Octavia Combi III (obr. 1, tab. 3).

Následky nehody:

- Spolucestující ve vozidle Suzuki (71 let) nepřežil následky střetu, řidič (27 let) utrpěl těžká zranění - poranění hrudníku, páteře, břicha a dolních končetin (poranění vnitřních orgánů, páteře, zlomenina pánve).

- Cestující ve vozidle Škoda nebyli v důsledku nehody zraněni. 


\subsection{Př́ípad 2}

K dopravní nehodě došlo v obci, přičemž řidič vozidla Seat Leon nedal př̀ednost osobnímu vozidlu Škoda Octavia přijíždějícímu po hlavní komunikaci z pohledu řidiče vozidla Seat zleva. V důsledku nehody došlo k nárazu vozidla Škoda do levého boku vozidla Seat v oblasti levých předních dveří (obr. 2, tab. 4).

Následky nehody:

- K Ridič vozidla Seat utrpěl pouze lehká zranění krku a ramene.

- Řidič vozidla Škoda nebyl v důsledku nehody zraněn (náraz zepředu, pro posouzení irelevantní).

\subsection{Př́ípad 3}

Řidič vozidla Renault Laguna jel po silnici v extravilánu a rozhodl se otočit do protisměru. $\mathrm{V}$ té době projížděl $\mathrm{v}$ témže směru za vozidlem Renault řidič vozidla Škoda Octavia, který při otáčení vozidla Renault narazil do jeho levého boku v oblasti levých předních dveří (obr. 3, tab. 5).

Následky nehody:

- Řidič vozidla Renault (44 let; náraz z boku) byl v důsledku dopravní nehody těžce zraněn v oblasti hlavy, hrudníku, břicha a kyčle (zlomeniny a poranění vnitřních orgánů).

- K Ridič vozidla Škoda (34 let; náraz čelní) utrpěl lehká zranění v podobě zranění klíční kosti, hrudníku, břicha a kolen.

\subsection{Př́ípad 4}

Řidič osobního vozidla Škoda Superb se rozhodl předjíždět vozidlo Volkswagen Touran v tom samém okamžiku, kdy vozidlo Volkswagen odbočovalo doleva na vedlejší komunikaci. Vozidlo Škoda pak narazilo do levého boku vozidla Volkswagen v oblasti levých předních dveří (obr. 4, tab. 6).

Následky nehody:

- Řidič vozidla Volkswagen (39 let; náraz zboku) v důsledku dopravní nehody utrpěl lehká zranění dolních končetin $\mathrm{v}$ podobě pohmožděnin.
- Cestující ve vozidle Škoda nebyli zraněni (náraz PP rohem).

\subsection{Př́pad 5}

Po projetí levotočivého směrového oblouku ztratil řidič vozidla Volkswagen Passat kontrolu nad vozidlem z důvodu ztráty jízdní stability, načež vozidlo vyjelo mimo pozemní komunikaci a narazilo bočně do stromu (obr. 5, tab. 7).

Následky nehody:

- Ǩidič vozidla Volkswagen (28 let; náraz bočně do stromu) na místě podlehl svým zraněním.

\subsection{Př́ípad 6}

Řidič vozidla Kia Cee'd se ve snaze zamezit kolizi s protijedoucím vozidlem vyhnul vpravo, přičemž dostal smyk, vyjel mimo pozemní komunikaci a narazil do stromu levým bokem vozidla Kia (obr. 6 , tab. 8).

Následky nehody:

- Řidič vozidla Kia (36 let; náraz bočně do stromu) utrpěl $\mathrm{v}$ důsledku nehody lehká zranění v podobě otřesu mozku, pohmoždění hrudníku a odřenin levého lokte a levého stehna. Spolucestující na zadních sedadlech (děti předškolního věku) neutrpěly žádná zranění (obě děti byly usazeny v dětských autosedačkách).

\section{DISKUSE A ZÁVĚR}

V článku jsou názorně představeny případové studie, které měly za úkol především upozornit na znatelný rozdíl v tuhosti karoserie a vybavení bezpečnostními prvky mezi starými a moderními vozidly. Porovnávané dopravní nehody se staly mezi lety 2014 a 2018, aktuálnost řešené problematiky je dána faktem, že v roce 2018 dosáhlo průměrné stárí osobních vozidel registrovaných v ČR hodnoty téměř 15 let.

Tab. 2 Porovnání následků střetu do boků vozidel.

Tab. 2 Vehicles side impact consequences comparison.

\begin{tabular}{|c|c|c|c|c|c|c|}
\hline $\begin{array}{l}\text { Př́ípad } \\
\text { č. }\end{array}$ & Vozidlo & $\begin{array}{c}\text { Rok výroby } \\
\text { vozidla }\end{array}$ & Typ střetu & $\begin{array}{c}\text { Aktivované } \\
\text { airbagy }\end{array}$ & $\begin{array}{c}\text { Rychlost } \\
\text { nárazu }\end{array}$ & Následky nehody \\
\hline 1 & $\begin{array}{l}\text { Suzuki Swift } \\
1.3 \mathrm{GSL}\end{array}$ & 1997 & $\begin{array}{l}\text { přejel do protisměru, dostal smyk } \\
\text { a bočně do vozidla suzuki narazilo } \\
\text { vozidlo Škoda Octavia Combi III. }\end{array}$ & $\begin{array}{l}\text { čelní na straně } \\
\text { řidiče i spolujezdce }\end{array}$ & $46 \mathrm{~km} / \mathrm{h}$ & $\begin{array}{l}\text { těžké zranění řidiče } \\
\text { a smrtelné zranění } \\
\text { spolujezdce }\end{array}$ \\
\hline 2 & $\begin{array}{l}\text { Seat Leon III } \\
1.4\end{array}$ & 2013 & $\begin{array}{l}\text { nedal přednost osobnímu vozidlu } \\
\text { Škoda Octavia přijíždějícímu } \\
\text { po hlavní komunikaci zleva }\end{array}$ & $\begin{array}{l}\text { střešní a sedadlový } \\
\text { airbag na straně } \\
\text { řidiče }\end{array}$ & $45 \mathrm{~km} / \mathrm{h}$ & lehké zranění řidiče \\
\hline 3 & $\begin{array}{l}\text { Renault Laguna } \\
\text { Grandtour } 1.9 \\
\text { dTi }\end{array}$ & 2000 & $\begin{array}{l}\text { Škoda Octavia při otáčení vozidla } \\
\text { Renault narazila do jeho levého } \\
\text { boku }\end{array}$ & žádné & $70 \mathrm{~km} / \mathrm{h}$ & těžké zranění řidiče \\
\hline 4 & $\begin{array}{l}\text { Volkswagen } \\
\text { Touran II } 1.6 \\
\text { TDI }\end{array}$ & 2012 & $\begin{array}{l}\text { náraz z boku při předjíždění } \\
\text { vozidla odbočujícího doleva }\end{array}$ & $\begin{array}{l}\text { střešní airbag } \\
\text { na straně řidiče }\end{array}$ & $70 \mathrm{~km} / \mathrm{h}$ & lehké zranění řidiče \\
\hline 5 & $\begin{array}{l}\text { Volkswagen } \\
\text { Passat 1.9 TDI }\end{array}$ & 1999 & $\begin{array}{l}\text { náraz levými předními dveřmi } \\
\text { do vzrostlého stromu }\end{array}$ & žádné & $50 \mathrm{~km} / \mathrm{h}$ & smrtelné zranění řidiče \\
\hline 6 & $\begin{array}{l}\text { Kia Cee'd } 1.6 \\
\text { CRDi }\end{array}$ & 2009 & $\begin{array}{l}\text { náraz levými předními dveřmi } \\
\text { do vzrostlého stromu }\end{array}$ & $\begin{array}{l}\text { sedadlový a střešní } \\
\text { na straně řidiče }\end{array}$ & $47 \mathrm{~km} / \mathrm{h}$ & $\begin{array}{l}\text { lehké zranění řidiče, cestující } \\
\text { na zadních sedadlech (děti } \\
\text { v autosedačkách) bez zranění }\end{array}$ \\
\hline
\end{tabular}



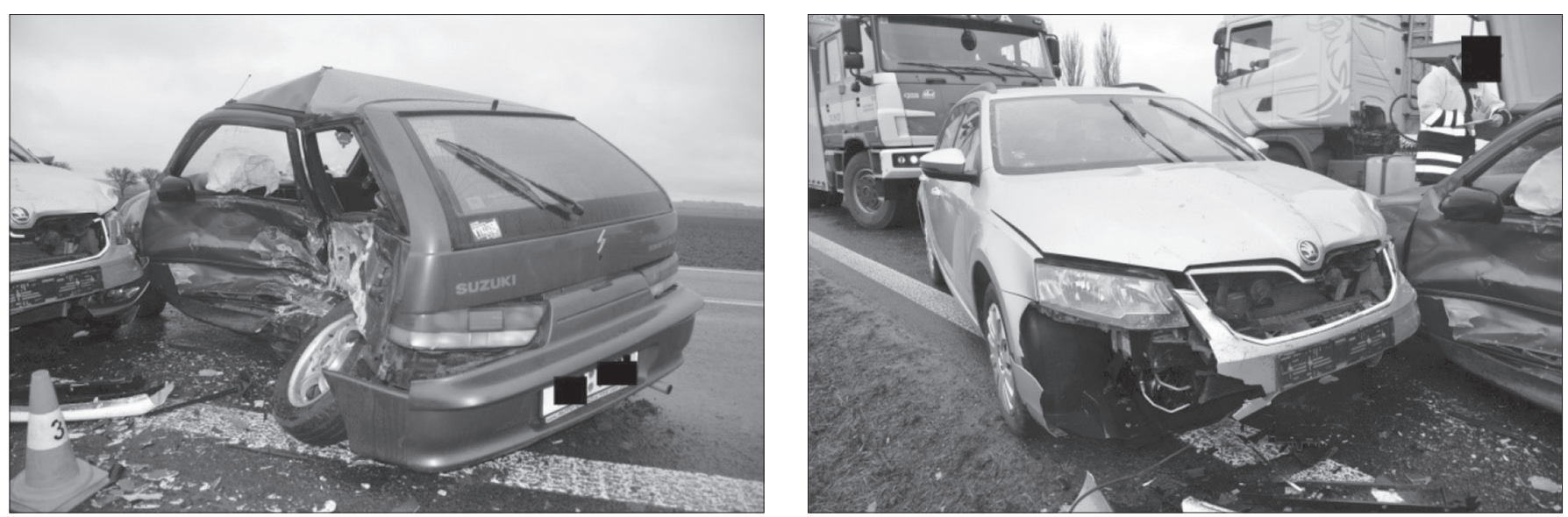

Obr. 1 Dopravní nehoda vozidel Suzuki a Škoda.

Fig. 1 Traffic accident of vehicles Suzuki and Škoda.

Tab. 3 Technické údaje nehody 1.

Tab. 3 Technical specifications of accident no. 1.

\begin{tabular}{lcc}
\hline Vozidla & Suzuki Swift 1.3 GSL & Škoda Octavia Combi III 1.8 TSI \\
\hline Rok výroby vozidla & 1997 & 2013 \\
Pohotovostní hmotnost & $1050 \mathrm{~kg}$ & $1305 \mathrm{~kg}$ \\
Počet cestujících & 2 & 2 \\
Střetová rychlost & cca $20 \mathrm{~km} / \mathrm{h}$ & cca $46 \mathrm{~km} / \mathrm{h}$ \\
Airbagy ve vozidle & čelní na straně řidiče a spolujezdce & čelní, sedadlové a střešní na straně řidiče a spolujezdce, \\
Aktivované airbagy & čelní na straně řidiče a spolujezdce & čelní na straně řidiče a spolujezdce, kolenní airbag řidiče \\
\hline
\end{tabular}
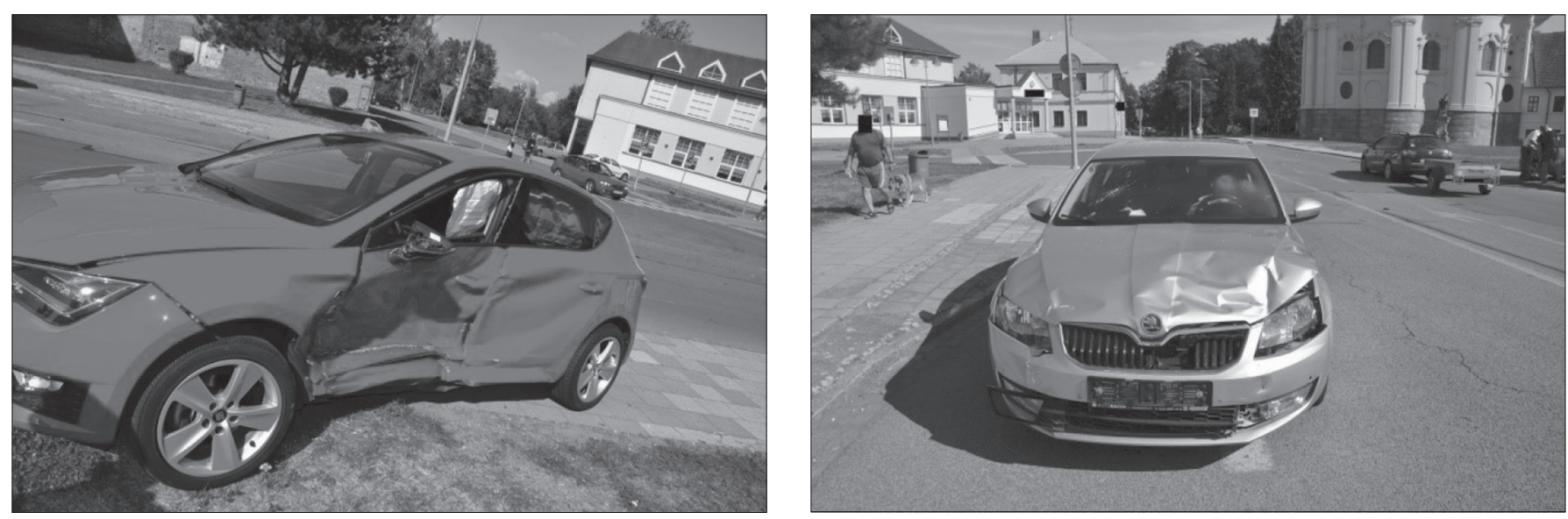

Obr. 2 Dopravní nehoda vozidel Seat a Škoda.

Fig. 2 Traffic accident of vehicles Seat and Škoda.

Tab. 4 Technické údaje nehody 2.

Tab. 4 Technical specifications of accident no. 2.

\begin{tabular}{|c|c|c|}
\hline Vozidla & Seat Leon III 1.4 & Škoda Octavia III 2.0 \\
\hline Rok výroby vozidla & 2013 & 2013 \\
\hline Pohotovostní hmotnost & $1098 \mathrm{~kg}$ & $1350 \mathrm{~kg}$ \\
\hline Počet cestujících & 1 & 1 \\
\hline Střetová rychlost & $\operatorname{cca} 7 \mathrm{~km} / \mathrm{h}$ & cca $45 \mathrm{~km} / \mathrm{h}$ \\
\hline Airbagy ve vozidle & $\begin{array}{c}\text { čelní, sedadlové a střešní na straně řidiče } \\
\text { a spolujezdce }\end{array}$ & $\begin{array}{c}\text { čelní, sedadlové a střešní na straně řidiče a spolujezdce, } \\
\text { kolenní airbag řidiče }\end{array}$ \\
\hline Aktivované airbagy & střešní a sedadlový airbag na straně řidiče & čelní na straně řidiče a spolujezdce, kolenní airbag řidiče \\
\hline
\end{tabular}



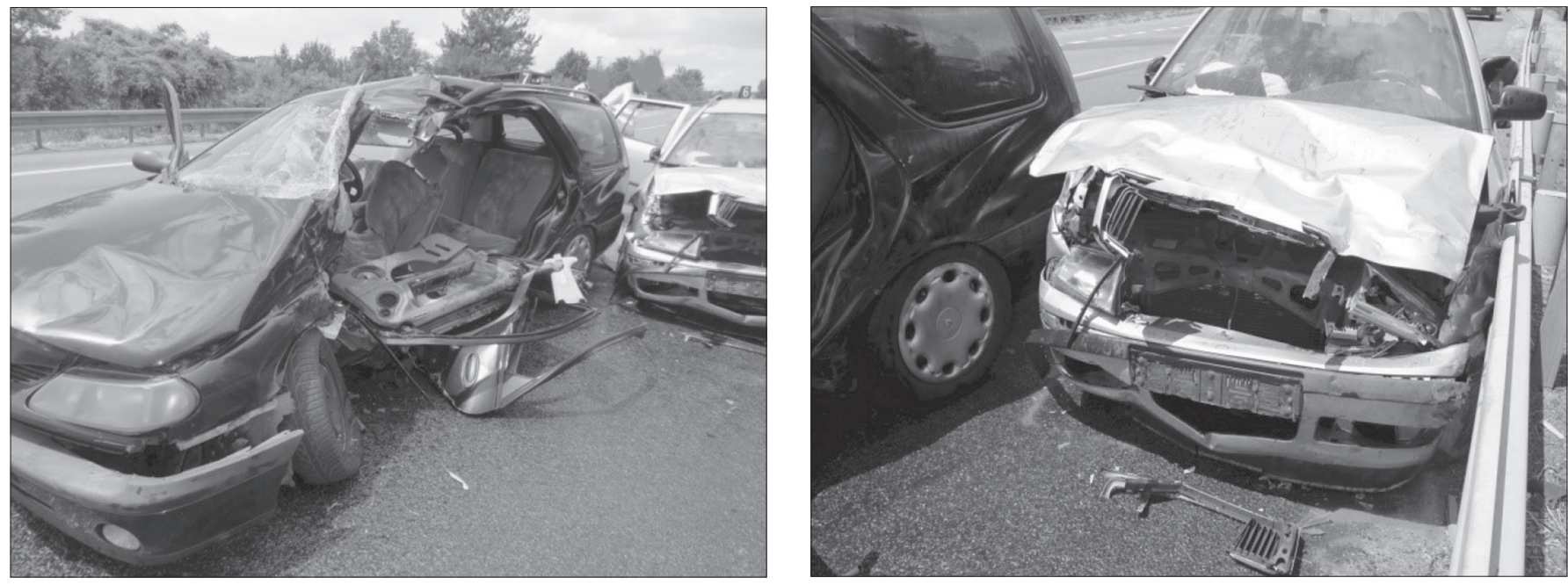

Obr. 3 Dopravni nehoda vozidel Renault a Škoda.

Fig. 3 Traffic accident of vehicles Renault and Škoda.

Tab. 5 Technické údaje nehody 3

Tab. 5 Technical specifications of accident no. 3 .

\begin{tabular}{lcc}
\hline Vozidla & Renault Laguna Grandtour 1.9 dTi & Škoda Octavia I Combi 1.9 TDi \\
\hline Rok výroby vozidla & 2000 & 2001 \\
Pohotovostní hmotnost & $1360 \mathrm{~kg}$ & $1360 \mathrm{~kg}$ \\
Počet cestujících & 1 & 1 \\
Střetová rychlost & cca $10 \mathrm{~km} / \mathrm{h}$ & cca $70 \mathrm{~km} / \mathrm{h}$ \\
Airbagy ve vozidle & čelní na straně řidiče a spolujezdce & čelní na straně řidiče a spolujezdce \\
Aktivované airbagy & žádné & čelní na straně řidiče a spolujezdce \\
\hline
\end{tabular}
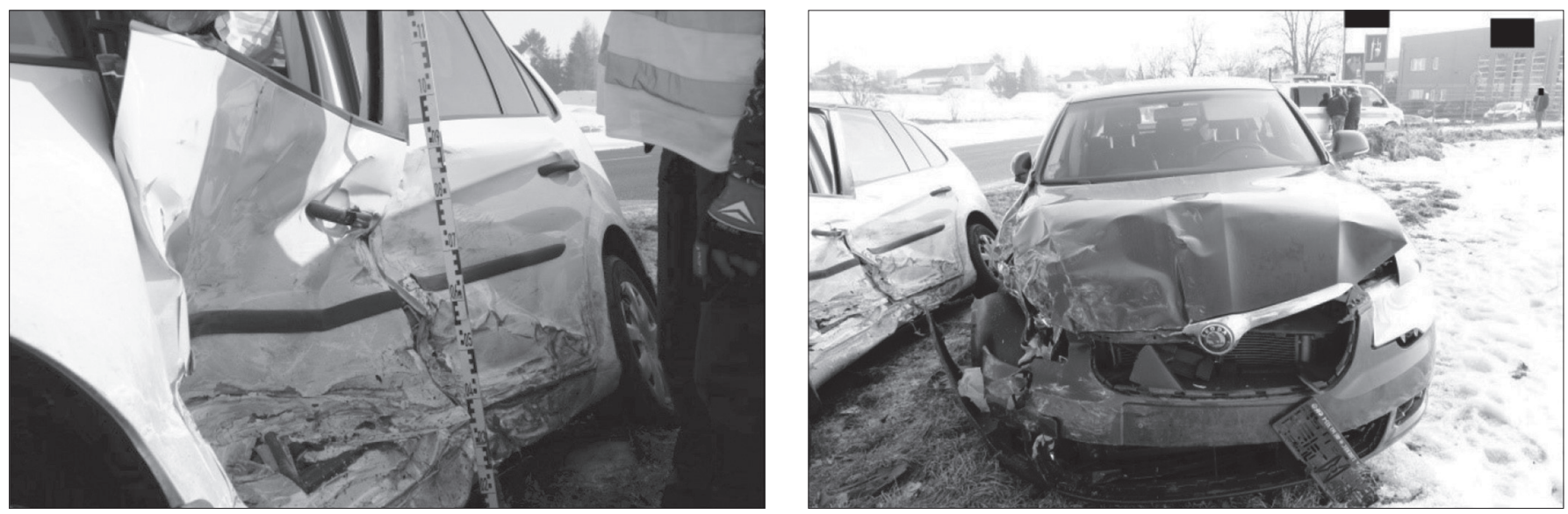

Obr. 4 Dopravní nehoda vozidel Volkswagen a Škoda.

Fig 4 Traffic accident of vehicles Volkswagen and Škoda.

Tab. 6 Technické údaje nehody 4.

Tab. 6 Technical specifications of accident no. 4.

\begin{tabular}{lcc}
\hline Vozidla & Volkswagen Touran II 1.6 TDI & Škoda Superb II 2.0 TDI \\
\hline Rok výroby vozidla & 2012 & 2005 \\
Pohotovostní hmotnost & $1444 \mathrm{~kg}$ & $1487 \mathrm{~kg}$ \\
Počet cestujících & 1 & 2 \\
Střetová rychlost & cca $25 \mathrm{~km} / \mathrm{h}$ & cca $70 \mathrm{~km} / \mathrm{h}$ \\
Airbagy ve vozidle & čelní, sedadlové a střešní na straně řidiče & čelní, sedadlové a střešní na straně řidiče a spolujezdce, \\
Aktivované airbagy & a spolujezdce & kolenní airbag řidiče \\
& střešní na straně řidiče & čelní a kolenní na straně řidiče
\end{tabular}



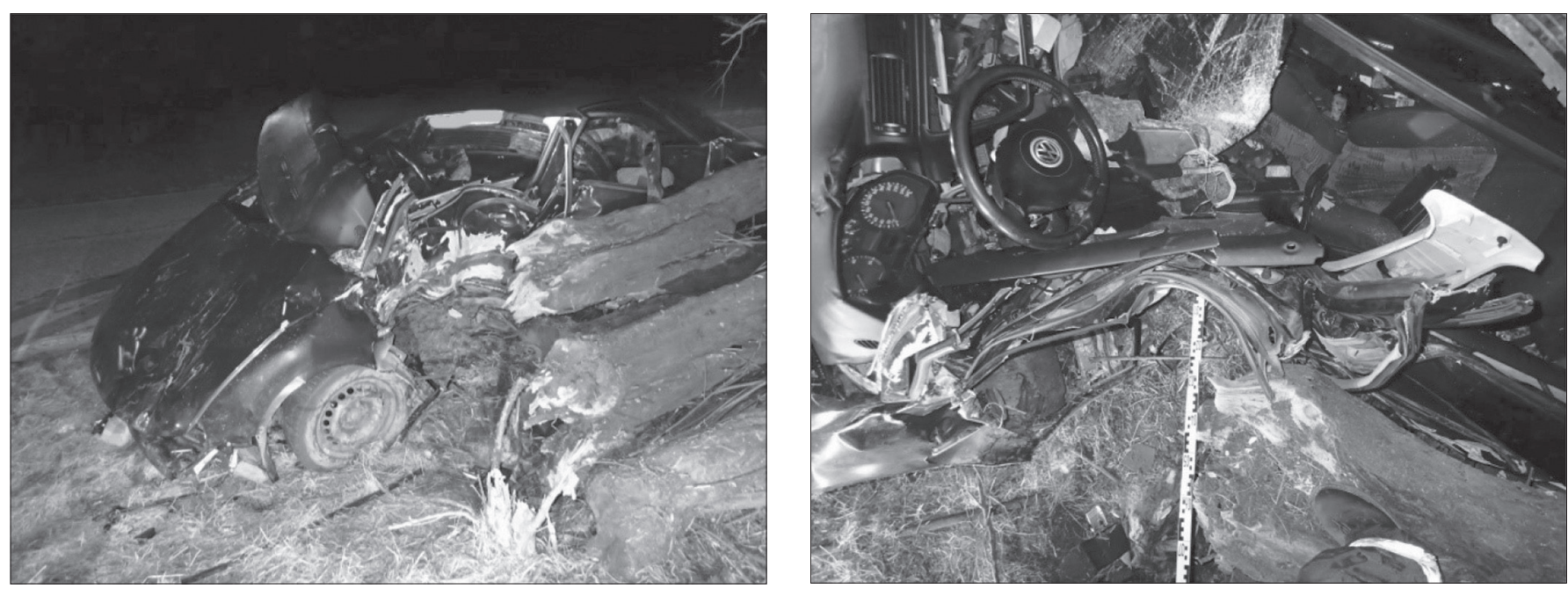

Obr. 5 Dopravní nehoda vozidla Volkswagen.

Fig. 5 Traffic accident of vehicle Volkswagen.

Tab. 7 Technické údaje nehody 5.

Tab. 7 Technical specifications of accident no. 5 .

\begin{tabular}{lc}
\hline Vozidlo & Volkswagen Passat 1.9 TDI \\
\hline Rok výroby vozidla & 1999 \\
Pohotovostní hmotnost & $1405 \mathrm{~kg}$ \\
Počet cestujících & 1 \\
Střetová rychlost & cca $50 \mathrm{~km} / \mathrm{h}$ \\
Airbagy ve vozidle & čelní na straně řidiče a spolujezdce \\
Aktivované airbagy & žádné \\
\hline
\end{tabular}
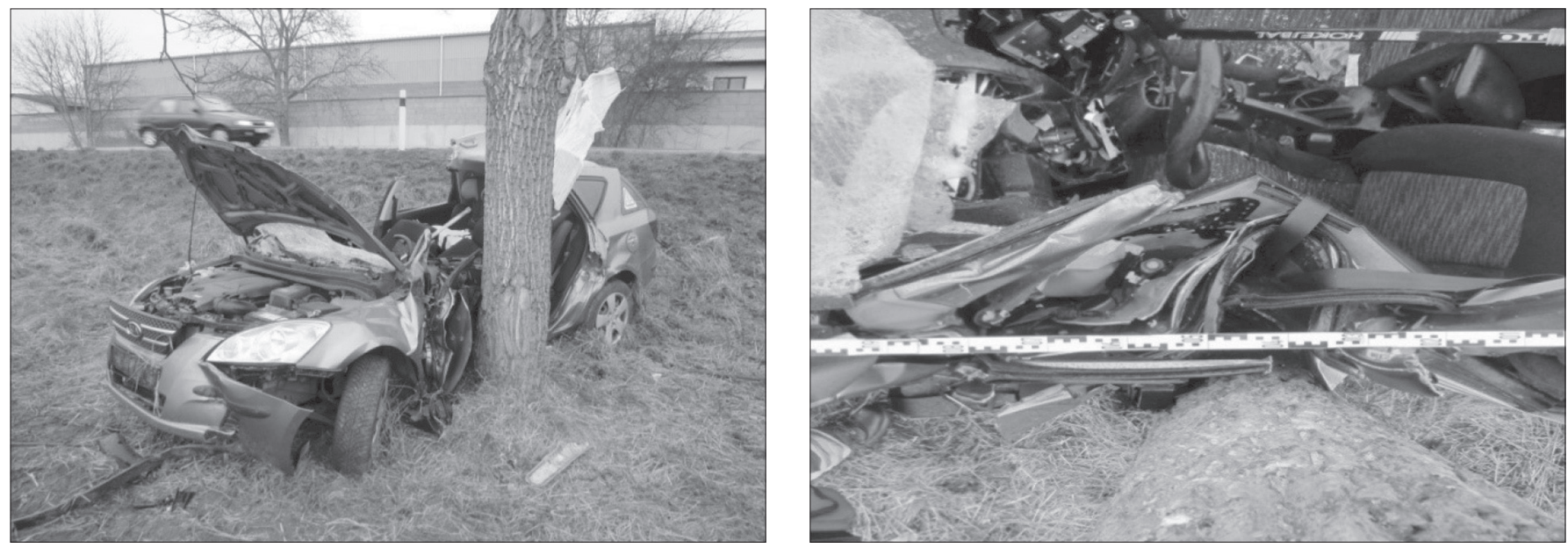

Obr. 6 Dopravni nehoda vozidla Kia.

Fig. 6 Traffic accident of vehicle Kia.

Tab. 8 Technické údaje nehody 6.

Tab. 8 Technical specifications of accident no. 6 .

Vozidlo

Rok výroby vozidla

Pohotovostní hmotnost

Počet cestujících

Střetová rychlost

Airbagy ve vozidle

Aktivované airbagy

Kia Cee'd 1.6 CRDi

2009

$1257 \mathrm{~kg}$

3

cca $47 \mathrm{~km} / \mathrm{h}$

čelní, sedadlové a střešní na straně řidiče a spolujezdce sedadlový a stř̌šní na straně řidiče 
Z porovnání jednotlivých případových studii je patrný poměrně značný rozdíl, at' už se jedná o deformace vozidla či následky na zdraví jednotlivých cestujících ve vozidlech. Vliv stáří analyzovaných vozidel u bočních střetů byl především zaznamenán v rozdílné vybavenosti vozidel airbagy a tuhosti jednotlivých dílů karoserie vozidla. Podobné závěry představili i autoři článku [2], kde bylo uvedeno, že rozdíly následků starých a nových vozidel je dán nejen rozdílem konstrukce vozidel, ale také jejich vybavením zádržnými systémy. Rovněž autoři článku [8] poukázali na snížení rizika vzniku těžkých a smrtelných zranění v souvislosti s novějším modelovým rokem vozidel.

V představených př́padech bočních střetů je pak mezi starými a novými vozidly kromě roku výroby patrný rozdíl ve vybavení moderních vozidel bočními airbagy, které mají značný vliv na následky dopravních nehod. Stejně tak bylo pozorováno snížení zranění u tohoto typu střetů v souvislosti s bočními airbagy ve studii [7], která se zabývala především poraněním hlavy. Porovnání následků dopravních nehod starých a moderních vozidel nabízí tab. 8 .

Z pohledu soudně inženýrské praxe se při vyhodnocení střetových rychlostí začíná projevovat zastaralost běžně používaného katalogu EES [12], resp. vozidel, která jsou v katalogu zahrnuta a to zásadním způsobem právě při vyhodnocování bočních střetů vozidel. Posuzování deformací moderních vozidel na základě komparační metody sebou nese značnou míru nepřesnosti, která může vést $\mathrm{k}$ chybnému stanovení střetové rychlosti. Při analýze deformací vozidel se tak jeví potřeba přesnější dokumentace rozsahu poškození, než kterou je schopna poskytnou běžná fotodokumentace, podle které by bylo možné přesně vyhodnotit hloubku deformace. Takto provedenou dokumentaci deformace vozidel je pak možné použít při určení EES pomocí výpočetních programů (např. CRASH 3), které zohledňují tuhost vozidel, určenou vyhodnocením nárazových zkoušek reálných vozidel.

Tento článek byl vytvořen za finanční podpory Ministerstva školství, mládeže a tělovýchovy v rámci programu Národní program udržitelnosti I, projektu Dopravní VaV centrum (LO1610) na výzkumné infrastruktuře pořízené z Operačního programu Výzkum a vývoj pro inovace (CZ.1.05/2.1.00/03.0064).

\section{LITERATURA}

[1] ACIERNO, S. et al. Vehicle mismatch: injury patterns and severity. Accident Analysis \& Prevention, 2004, 36(5), s. 761772 .

[2] BLOWS, S. et al. Vehicle year and the risk of car crash injury. Injury Prevention. 2003, 9(4), s. 353-356.

[3] GABLER, H. C., HOLLOWELL, W. T. The aggressivity of light trucks and vans in traffic crashes. SAE Technical Paper, 1998.

[4] GAYLOR, L., JUNGE, M., ABANTERIBA, S. Efficacy of seatmounted thoracic side airbags in the German vehicle fleet. Traffic injury prevention, 2017, 18(8), s. 852-858.

[5] GIERCZYCKA, D., CRONIN, D. Influence of the chest compression measurement method on assessment of restraint performance in side-impact crash scenarios. Journal of biomechanics, 2018.

[6] GURSEL, K. T., NANE, S. N. Non-linear finite element analyses of automobiles and their elements in crashes. International Journal of Crashworthiness, 15:6, 2010, 667-692, DOI: $10.1080 / 13588261003737286$.

[7] MCGWIN JR, G. et al. Association between side air bags and risk of injury in motor vehicle collisions with near-side impact. Journal of Trauma and Acute Care Surgery, 2003, 55(3), s. $430-436$.

[8] RYB, G. E., DISCHINGER, P. C., HO, S. Vehicle model year and crash outcomes: a CIREN study. Traffic injury prevention, 2009, 10(6), s. 560-566.

[9] SUMMERS, S., HOLLOWELL, W. T., PRASAD, A. NHTSA's research program for vehicle compatibility. In: Eighteenth International ESV Conference, Paper. 2003.

[10] TOKAŘ, S., SEMELA, M., BILÍK, M., BRADÁČ, A. Comparison Of Selected Impact Parameters By Side Vehicle Crash Tests With Computational Software Results. In: International Conference on Traffic and Transport Engineering ICTTE. Belgrade, Serbia: Scientific Research Center Ltd Belgrade, 2016. s. 634-641. ISBN 978-86-916153-3-8.

[11] TAY, Y. Y., LIM, Ch. S., LANKARANI, H. M. A finite element analysis of high-energy absorption cellular materials in enhancing passive safety of road vehicles in side-impact accidents. International journal of crashworthiness, 2014, 19(3), s. $288-300$.

[12] MELEGH, G., VIDA, G. CD-EES 2005, AutoExpertHungary, 1997-2005 - online verze.

\section{Správná citace:}

MIKULEC, R., DVOŘÁKOVÁ, P. Případová studie vlivu stáří vozidel na zranění cestujících. Soudní inženýrství, 2019, 30(1), 2-8. DOI: http://dx.doi.org./10.13164/SI.2019.1.2. ISSN 1211-443X. 